\title{
TRAVELLERS, EASTER WITCHES AND CUNNING FOLK: REGULATORS OF FORTUNE AND MISFORTUNE IN OSTROBOTHNIAN FOLKLORE IN FINLAND
}

\author{
KAROLINA KOUVOLA \\ Doctoral Student \\ Department of Culture / Study of Religions \\ University of Helsinki \\ P.O. Box 59 (Unionkatu 38E) \\ 00014 Helsinki, Finland \\ e-mail: karolina.kouvola@helsinki.fi.
}

\begin{abstract}
This article ${ }^{*}$ is about the distinct groups that practised malevolent and benevolent witchcraft in Swedish-speaking Ostrobothnia in late-modern Finland according to belief legends and memorates. Placing belief legends and memorates in Mary Douglas' tripartite classification of powers that regulate fortune and misfortune illuminates the social structure of agents who posed a threat or regulated it by means of their supranormal powers. Powers that bring misfortune dwell outside or within the community, whereas powers that bring fortune live within it but nevertheless may be ambivalent and pose a threat to its members as well. Threat towards the community was based on the concept of limited good, in other words the belief that there was a finite amount of prosperity in the world. The aim is to paint a detailed picture of the complex social structure and approaches to witchcraft in late-modern Swedish-speaking Ostrobothnia.

KEYWORDS: witchcraft $\bullet$ cunning folk $\bullet$ folk healing $\bullet$ folk belief $\bullet$ benevolent magic
\end{abstract}

\section{INTRODUCTION}

This article concerns the folklore of the Swedish-speaking minority in late-modern Ostrobothnia, Finland, the aim being to study how various users of witchcraft were understood within the context of limited good in this Swedish-speaking community. I suggest that Mary Douglas' (2002 [1966]: 130) notion of a triad of power that controls fortune and misfortune in a community facilities the drawing of three distinct groups

* I wish to thank the two anonymous reviewers for their insightful comments on an earlier version of this article and Joan Nordlund for her help with language revision. The article has been supported by a grant from The Swedish Cultural Foundation in Finland. 
from Swedish-language folklore in Ostrobothnia, Finland. This is supported by the distinction made in archived textual material between an outgroup of people who posed a threat to the community, an ingroup of people who threatened the community from within, and the cunning folk in the ingroup who helped to regulate and resolve this threat. The last group of this triad comprised persons who used specialised knowledge unknown to other members of the community. The result is an onion-like structure in which the outgroup of threats constitutes the outer layer, threats from within the community constitute a second layer, and the cunning folk are in the centre, closest to members who did not possess the required witchcraft skills and therefore needed specialised help. This social structure relies on the concept of 'limited good', which was first mentioned in international scholarship by George M. Foster in 1965 and has affected belief legends and narratives about these groups and their supranormal powers. However, in the context of Finnish scholarship, Toivo Vuorela had already concluded in 1960 that the agricultural society in Finland had a concept that implied that there was only a limited amount of good in the world (see Stark 2004: 71-72).

The folklore material used in this article was collected in the Swedish-speaking region of Ostrobothnia. As a region, Ostrobothnia constitutes a unique example of the Swedish-language folk culture in Finland in that most of the currently available data on Swedish-language folklore was collected here in the 19th and 20th centuries. It seems from the material that there were also strong prejudices against Ostrobothnians with their skills in witchcraft in other Swedish-speaking regions of Finland (see for example SLS 33: 108-110; SLS 91: 41-42; SLS 116a: 38-40; SLS 531: 464-465). In the article I reveal additional information about how the Swedish-speaking community evaluated individuals who practiced witchcraft, which enhances understanding of how the folk culture of Swedish-speaking Finland categorised supranormal threats as part of the community's social construction.

Belief legends and memorates collected from Swedish-speaking Ostrobothnia constitute the primary source material for this article. The corpus contains 299 different narratives from several regions in Ostrobothnia, most of which are agricultural communities: the only urban exception is the town of Vasa. This material is analysed in accordance with the work of Douglas (2002 [1966]) and her triad of powers in a community, the aim being to study how the concept of limited good affected belief narratives.

In the following I briefly describe the nature of bilingualism in Ostrobothnia and other Swedish-speaking regions in Finland before going on to explain the material corpus analysed in this article. Then I explore Douglas' triad of powers that control fortune and misfortune, and the concept of limited good. After that I examine more closely the powers from outside of the community, the threats from within the community and the cunning folk as controllers of both fortune and misfortune inside the community. The article ends with a short concluding paragraph.

\section{B I L INGUAL OSTROBOTHNIA}

The coastal areas of Finland have been bilingual for centuries. Both Swedish- and Finnish-speaking populations have existed contiguously at least from medieval times when Swedish-speakers migrated mainly from the Märaldalen, Hälsingland, and Gästrikland 
regions to Åland, Ostrobothnia, Nyland, and the Åbo archipelago, where there were only a few Finnish-speaking communities. (Bladh and Kuvaja 2005: 17) Swedish-speaking Ostrobothnia extended from Karleby to Sideby in the 19th and at the beginning of the 20th century, forming a region of about 250 kilometres in length that was characterised by small villages and a few towns (Herberts and Vähämäki 1998: 21-22). People from different social backgrounds spoke either Swedish or Finnish, or they were bilingual. Although most of the peasantry in the Swedish-speaking regions were Finnishspeaking whereas Swedish was spoken by the higher classes, boundary-crossing was possible despite the language differences - occurring most commonly when a Finnishspeaker changed his/her language to Swedish. (Lindgren and Lindgren 2005: 258-259) Even though these regions could be described as bilingual to some extent, the first folklore-collecting efforts in the 19th century focused on Finnish-language folklore material in line with nationalistic tendencies. It was only later that collectors expressed a direct interest in Swedish-Finnish folklore. (Österlund-Pötzsch and Ekrem 2008: 19-20) Language did not seem to affect how the cunning folk were narrated in folklore. However, when it came to the generalisation of malevolent or mythic beings there are few examples of their speaking the minority language.

\section{BELIEF LEGENDS AND MEMORATES ABOUT WITCHCRAFT IN OSTROBOTHNIA}

The material discussed in this article is based on folklore data that has been published in Finlands Svenska folkdiktning II Sägner: 3 mytiska sägner (Wessman 1931) and Finlands Svenska folkdiktning VII. Folktro och trolldom. 5 Magisk Folkmedicin (Forsblom 1927). I have included belief legends and memorates from two sections Häxor, trollkarlar, trollkunniga personer, frimurare ('Witches, male witches, persons with skills in witchcraft, freemasons') and Omlagning och omlagare ('Healing and healers'). However, I have excluded frimurare 'freemasons' from the material covered in this article because the belief legends about them are different from those about trollkarlar 'male witches', for example, and they do not present a perceived threat to the community. It is worth noting that this printed material only offers guidance in terms of what to look for in the archived material that constitutes the field notes and the informants' narrations in the form in which the collectors have written them. In some cases the published belief legends and memorates closely resemble the archived material, but in general the published version is a summary of it and gives no further details about the informants or their backgrounds. I have therefore collected material from the archives of the Society of Swedish Literature in Finland (SLS), which also holds archived versions of the published material. In all, a total of 299 memorates and belief legends from Swedish-speaking Ostrobothnia constitute the material corpus examined in this article.

In the latter half of the 19th century scholars in Finland became aware that the folk culture of the Swedish-speaking minority needed to be preserved. Consequently, The Society of Swedish Literature in Finland (Svenska Litteratursällskapet i Finland) was established in 1885, with the aim of collecting Swedish-language folklore as well as preserving and publishing it. (Asplund Ingemark 2006: 5) SLS published a circular in the 1880s calling for interested parties to collect folklore from Finland's Swedish-speaking 
minority. Charms were grouped with traditional practices and customs, whereas häxor 'witches' as a category were grouped with tales and legends. (Andersson 1967: 193-194) Interestingly, the word häxor is rarely mentioned in the folklore data, whereas words such as trollkarl, trollkäring 'female witch', or trollgumma 'old female witch' appear more frequently in belief legends and memorates, meaning an active healer. This could indicate that practices associated with cunning folk were still prevalent in agricultural communities even though the academic view, which the SLS represented, was that they belonged to the folktale genre and were not active customs.

The circular also offered special advice to those who decided to collect charms: old men and women tended to be the most reliable informants on matters to do with charms and other related information. Fieldworkers were also advised to be careful when asking about witchcraft and folk beliefs because it was difficult to find people who were willing to talk about such matters with collectors whom they had not met before. (Ibid.: 195)

The SLS entrusted academic scholars with the collecting of folklore in 1909, whereas earlier it had been done by local teachers, for example. As a result, the social and education gap between the collectors and the informants widened, which probably affected what the latter shared with the former. The collectors may also have modified the folklore material according to what they thought their employers in society wanted to read about, and they focused on themes that were personally interesting to them. (Asplund Ingemark 2006: 5-6) One of the informants who responded to questions about local cunning folk indicated that they wanted to remain anonymous in the archives (FMK 158 a: 370). Unfortunately, because the collectors were instructed to keep contextual information to a minimum (Asplund Ingemark 2006: 6), one can only guess why anonymity was preferred in some cases. I suggest that it was because the informants did not wish to be perceived as spreading local gossip, or because they believed in the powers that the cunning folk were said to wield according to belief legends. However, one cannot conclude anything about what the informants might have thought about their narratives from the archived material (ibid.). Nevertheless, the communicative aspect of the material on folk beliefs is significant in itself, despite the lack of contextual information about the use of supranormal powers. The archived material still contains evidence of social tension and fear concerning prosperity, for example. (Stark 2004: 70-71)

\section{THE TRIAD OF POWERS CONTROLLING FORTUNE AND MISFORTUNE}

It was important in agricultural communities, in which people lived in close proximity and were able to compare their prospects with those of their neighbours, to regulate fortune and misfortune and to develop a coherent understanding of how supranormal powers affected lives. Behind the fear of being less prosperous than other members of the community is the concept of luck as the limiting good. According to this cultural model, ${ }^{1}$ there is a limited amount of luck in the world, hence if someone's cattle fell ill it might be blamed on a jealous neighbour or someone else who wielded harmful supranatural power. As an example, a folk narrative from Larsmo forbids people from telling their neighbours if their cows milk well: if they do so, the cows will start to give less 
milk (SLS 513: 142). This notion of a limited amount of luck was reinforced in the late 19th century when a great famine following a cold winter coincided with population growth (Stark 2004: 72).

According to Foster (1965: 296), peasant behaviour is based on the "Image of Limited Good", meaning that members of the peasant community perceive desired things such as wealth and prosperity as existing in "finite quantity" and as being "always in short supply". This applies to the folklore of Ostrobothnia as well. There was a limited amount of wealth, which meant that if one's neighbour was more successful than oneself, one's wealth automatically diminished. (Honko 1959: 101; Stark 2002: 40-41; Vuorela 2019 [1960]: 15)

Foster (1965: 296) continues: "there is no way directly within peasant power to increase the available quantities." I argue, however, that peasants could at least try to affect their environment by means of witchcraft or supranormal power. This follows Foster's argument that "an individual or a family can improve a position only at the expense of others" because the village community is a closed community. Another point worth making is that there was, in reality, a finite amount of prosperity to be gained from fields that produced only a certain amount of harvest, for example. (Ibid.: 296-298) This knowledge increased tensions between people who lived in close proximity to each other and could observe how successful others were. In fact, the folklore material includes straightforward instructions on how to steal luck from other members of the community (see for example SLS 527a: 348, 390), alongside belief legends that represent the same cultural model.

My aim is thus to analyse the Swedish-language folklore material from Ostrobothnia concerning limited good and the kind of people who practiced witchcraft in accordance with the belief legends. In doing so I apply Douglas' tripartite system or structure of people who wield supranatural power to bring fortune or misfortune to a rural village community. Douglas (2002 [1966]: 122) bases her idea of such a tripartite power structure on the notion that the community has an articulated form and is surrounded by non-form. Its members should therefore be aware of where powers that affect it come from, in other words from within the community or from outside of it. Given the role of personal agency in misfortune in terms of affecting other people's prosperity, it would be useful to classify personal intervention in the fortunes of others. Powers originate both internally, as an evil eye that a person cannot control, for example, and externally under the control of its users in the form of charms and blessings. (Ibid.) According to a similar cultural model in Swedish-speaking Ostrobothnia, an evil eye could forebode illness (see for example SLS 25: 356-357).

Some of these controlled and external supranormal powers are used on behalf of the community and are approved by it: their position of authority is recognised. On the other hand, there are malevolent powers of which the community does not approve and that are considered a threat. They are uncontrolled and internally used, and they threaten the community from the outside, imposed by persons who are in an ambiguous role. (Douglas 2002 [1966]: 123-124) According to Douglas (ibid.), these various powers stem from articulated and unarticulated communities, but I argue on the basis of my source material that they may dwell within the community, and that different persons exercise both kinds of power. With regard to Ostrobothnian folklore, this applies especially to people who generally exercise benevolent power. I will return to this question later in the article. 
Douglas (ibid.: 130) describes a triad of powers that control fortune and misfortune within a community:

[...] first, formal powers wielded by persons representing the formal structure and exercised on behalf of the formal structure: second, formless powers wielded by interstitial persons: third, powers not wielded by any person, but inhering in the structure, which strike against any infraction of form.

In line with Douglas (ibid.: 47, 130), I argue that groups not participating in the everyday life of the village communities symbolised anomalies that endangered the formal structure of the agricultural community. What these groups had in common was that their livelihood was not based on agriculture and they came from outside of the village community, therefore they represented formless powers wielded by interstitial persons. I further argue that powers that are inherent in the structure and not wielded by any person are presented in Swedish-speaking folklore as neighbours or other members of the community who practice witchcraft, especially during annual festivities or on other special occasions. Finally, the cunning folk of the community represent the formal powers authorised by it.

However, Douglas was critical of this tripartite structure, and like her I apply it loosely to my data using it merely as a categorising tool. She refers to sorcery as a form of controlled spiritual power and suggests that interstitial people should not, strictly speaking, exercise the controlled and symbolic power of the community. (Ibid.: 130) Applying this triad of powers, I aim to show that, in the belief legends and memorates, the power of interstitial people to violate the structure stems from the same social structure as the power of people who undo the supranormal damage inflicted by interstitial persons. According to belief legends, for example, these people could practice witchcraft that was otherwise also practiced by members of the society, such as thinking ill of someone and thereby causing him/her harm (see for example Spooner 2013 [1970]: 315 and Vuorela 2019 [1960]: 26 on the evil eye).

\section{POWERS THAT WIELD MISFORTUNE FROM OUTSIDE OF THE COMMUNITY}

Agricultural communities in Ostrobothnia were constantly struggling to cope given the resources that the subsistence economy provided. Memorates and belief legends about witchcraft and misfortune-wielding powers were used to regulate this behindthe-scenes conflict. Powers from outside the community form a separate sub-category in the narratives about this struggle. (Stark 2004: 71) If someone inflicted harm on a person's livestock, fields or health, the status quo was disturbed, and the balance had to be restored (Vuorela 2019 [1960]: 37). Groups of people are typically assigned simplified and stereotypical roles in the belief legends (Jauhiainen 1998: 18). This is also apparent in the Swedish-speaking folklore material of Ostrobothnia: people living outside of the community are not assigned individual traits, but are treated as a homogenous group, such as tattare ('travellers') or Laplanders, whose role is to present a supranormal threat.

The categorisation of things and persons is a necessary aspect in terms of understanding the world and arranging it symbolically (Lakoff 1987: 9). Such categorisation is 
apparent in the folklore material that members of the community produced and transmitted. The categories they outline form boundary lines that can be crossed. Growth, continuity and order in the community culture are based on the symbolic crossing of these categorical boundaries. In a hunter community, for example, the category 'inside' included villages and families and was distinguished from the category 'outside', where animals dwelled. (Anttonen 1996: 95-96) Categories that formed in Swedish-speaking Ostrobothnia also represent this cultural model of growth and order through symbolic boundary crossing. A person who was not part of the community or was in a liminal state represented a power that could cross bodily boundaries, for instance, and cause illness or steal another person's luck, thereby affecting cultural order and balance in the community in pursuit of personal success.

Several groups in the belief legends represented the supranormal threat that opposed the community from outside. These groups can be divided among belief legends about natural groups of persons who were in contact with members of the community and supranormal beings, who posed a threat that came from the mythical otherworld. Both of these groups practiced supranormal powers that brought misfortune to members of the community.

There are slight differences in how these groups are presented in the belief material. For example, Laplanders did not participate in village life, nor did they have a formalised place in it. They operated from outside the village, such as in the forest where they could jeopardise someone's hunting luck if they were shot while transformed into a bird and the hunter did not realise that they were Laplanders (SLS 220: 256-257), or from Lapland whence they could send illness projectiles. Some Laplanders were helpful in terms of teaching healing methods and how to bewitch a gun so that it would not release bullets (for example SLS 524: 280, 339-340). It seems that Laplanders had an ambivalent role in the belief narratives: they could cause illness and bewitch weapons, but they could also provide useful information on the use of supranormal powers.

The mythologisation of the North and of Laplanders is also apparent in the Finnishlanguage folklore of eastern Finland. According to folklore material from Vuokkiniemi in Karelia, good rune singing was associated with people from the North. Indeed, it is suggested that rune singers learned their craft from the North, or from Laplanders, who are also mentioned as helping them. (Tarkka 2013: 164) It thus seems that not all associations between the North and the supernatural were considered malevolent in folklore. Even in Vuokkiniemi, however, the North (Finnish Pohjola; the geographical equivalent of Lapland [Tarkka 2013: 174]) was a place to which illnesses were banished. The North was considered a symbol of the afterlife and therefore a "space bereft of the familiarity, warmth, and virtues associated with life" (ibid.: 385; see also ibid.: 388 and Siikala 2002: 98-99). These contradictory perceptions of the North may well have coexisted, at least in the Vuokkiniemi tradition. Moreover, being able to receive otherworldly power from a place like the North, despite the malevolent connotations, could be perceived as something that would increase a healer's power. (See for example Itkonen 1955: 193-194)

In other Swedish-speaking regions Ostrobothnians represented an outgroup that affected folklore (see for example FMK 139 b: 2133; SLS 33: 108-110). This also applies to the Finnish-speaking people of Ostrobothnia, who were reputedly skilful in the art of magic. According to belief legends, there were several well-known Finnish speakers who were capable of supernatural deeds, including Peilipoika 'Mirror Boy' (see Mattila 
2016). Ostrobothnian witchcraft was similarly depicted in these legends as the malevolent magic of other outgroups:

A man [Ostrobothnian] became angry because an old woman had not immediately promised that he could stay, but he said nothing, then when he had coffee he crept closer to the milk churn, and dropped a piece of sugar in it. The old woman churned and churned but did not get any butter. Again, the old woman was afraid, knowing that it was a witch who had come again with his tricks. She began to talk to him in a friendly matter, and said that if he gave her back her butter luck, he could have whatever he wanted. (SLS 319: 27-28; see also FMK 158 a: 536 on the belief legend of the Swedes who were convinced that Ostrobothnians could destroy their guns.)

This narrative is very similar to a belief legend from Munsala about the tattare, who had a wandering lifestyle and therefore lived outside of the village community: "My grandmother told me that when the travellers came and asked if they could buy butter they said that they would teach those who sold it to them how to churn butter from water" (SLS 581: 400). Becoming the subject of bewitchment due to inhospitality is a common theme in European belief legends about witchcraft (Thomas 1991 [1971]: 62). Malevolent witchcraft usually concerned rival families or members of the community, hence offering hospitality to the potential perpetrator could have a positive effect in terms of the type of witchcraft that was deemed appropriate (Vuorela 2019 [1960]: 82). Strong prejudices led to belief narratives describing how the tattare could make a person insane simply by taking his/her hand (SLS 513: 194).

The reputation of being able to practice malevolent magic protected outside groups of people who had to rely on the hospitality of others. Folk narratives preserve these mental models, including one in which a person does not become the subject of malevolent witchcraft. (Stark 2004: 76) These narratives represent a widely recognised pattern: a witch is denied the food supplies he or she requests and is turned away. Someone might hear him/her mumble some words when he or she leaves. After a while, something bad happens in the household and the witch is held responsible for it. (Thomas 1991 [1971]: 660-661) Lending equipment to and providing food for those in need were common customs in agricultural society (ibid.: 662-663). During the 1860s a poor harvest due to bad weather led to famine. Many people had no other choice than to travel from village to village begging for food. (SLS 533: 620-621) This might have affected belief legends concerning the provision of hospitality to beggars in order to evade malevolent witchcraft, although this topic needs further research.

This material concerns threats that come from outside the community. The beings in question were considered both natural as people with whom the villagers were most likely to be in contact, as well as supranormal and not living in the everyday world. However, there were those who lived in the same village context with the Swedishspeaking population, but who spoke Finnish instead of Swedish. These people are represented in the belief narratives as belonging both to a malevolent, threatening group and to a group that was similar to the Swedish-speaking community. 
Folklore material from Sweden represents Finnish speakers as witches (see for example ULMA 24345: 5-6 and ULMA 9408: 4). However, a Finnish-speaking cunning man could become as famous and as highly respected as his Swedish-speaking counterparts in bilingual Ostrobothnia, where both language communities had lived side by side for centuries. One belief legend tells of a cunning man called Håpiaseppä ('Silversmith') who rented a cottage in Gammelgård, Kimo, which he had exchanged with another Finn for two hundred giktringar (rings that were thought to ease rheumatism and gout) he had produced himself. Later the original tenant sold the giktringar and bought the cottage, and Håpiaseppä disappeared from Kimo about 60 years later. He is said to have healed people with hard liquor (FMK 158 a: 676), and to have taken one informant's father to a churchyard in Vörå and stood him in a ring that Håpiaseppä had drawn, while Håpiaseppä himself was in the church making deals with the dead (ibid.: 613).

At first glance, it might seem that Håpiaseppä had a wandering lifestyle because he moved in and out of Kimo. However, it was quite common in premodern society for artisans such as smiths and farmhands not to own land (Uotila 2018: 113). This did not necessarily make them outsiders in their society. However, one outsider in a Swedishspeaking community was an unnamed Finnish-speaking woman who lived with her husband in Nedervetil. A memorate describes how she used to shear sheep during the Easter period. Possibly because of the prejudices and rumours associated with this woman, a farmer accused her of wearing a dress that was similar to the one worn by the witch woman he had seen at Midsummer, sitting in a birch tree. When confronted about this, the Finnish-speaking woman denied that she was the same woman, even if she did have a similar dress. (SLS 211: 298-299)

Another belief legend from Övermark tells of a mythical creature skogsråd 'a lady of the forest' who visits a small farmhouse. When questioned, she answers in Finnish gibberish, and then she leaves. According to the legend, "She was a Finn and a witch woman, such as can be found in the forest" (SLS 524: 470). A Finnish-speaking woman is also said to have sent wolves into a village because she was not given the wool she had requested from farmhouses (SLS 527: 512).

As the memorate and belief legend described above show, even though speakers of Swedish and Finnish dwelled in the same region, there is evidence of disapproving attitudes in the folk narratives that represent members of the minority language group as outsiders, or the other. The narrative describing Håpiaseppä in church raising the dead for someone inside a protective circle is a common motif in this region, with different variants replacing Håpiaseppä with other cunning folk such as Himis-Hejk (FMK 158 a: 371), who appears in two of these narratives, or Vasjås-mossin (FMK 158 a: 32). However, replacing Håpiaseppä with other Swedish-speaking cunning folk places him in a similar position to other famous healers, despite the different language.

The supranormal and stereotypical threat that the aforementioned groups presented to the community justifies the fearful attitudes towards them in the belief legends (Douglas 2002 [1966]: 128-129). The same applies to the fear of witchcraft skills in Ostrobothnia and other Swedish-speaking regions in Finland. However, groups of people outside the social structure of the community could also engage in controlled witchcraft, in other words witchcraft that is not involuntary, such as exercising the evil eye 
without acknowledging it (ibid.: 130; SLS 531: 515). The same contradiction applies to people in powerful positions, such as the cunning folk, who practise malevolent magic when they should be protecting members of a community from it. Accusations of witchcraft within a community bring out the weak points in its social structure, as Keith Thomas (1991 [1971]: 68) suggests. Attitudes towards people from outside society concealed potential hostility, therefore belief legends and folk stories were composed about them (ibid.). However, hostility could also arise from within the community and lead to witchcraft accusations.

\section{THREATS FROM WITHIN THE COMMUNITY}

I will now move on to the third part of Douglas' (2002 [1966]: 130) triad, "powers not wielded by any person, but inhering in the structure, which strike against any infraction of form", presented here as the second category of groups representing a supranormal threat. I interpret 'powers that inhere in the structure' as threats that exist in a community and that pose a threat, especially on certain occasions. As Timothy R. Tangherlini (2000: 279) remarks, "A person, who could practice witchcraft and who also was an insider, was a great threat to a society." These people knew how the community functioned and could use its infractions to their own benefit. As a category of power users, the malevolent witches in Ostrobothnia were thought to be distinct from the cunning folk who practised benevolent magic, even though they could also engage in malevolent magic against members of their community (see also Thomas 1991 [1971]: 520).

One of the biggest threats from neighbours in Ostrobothnia was to livestock (27/299). Annual festivities such as Easter (SLS 254: 267), Shrovetide (SLS 220: 75) and Midsummer were popular times for stealing or harming livestock and the harvest by clipping the animal's fur or flesh (SLS 65: 62; SLS 554: 24; SLS 581: 8) or taking hay (SLS 524: 282), or ruining the butter. However, it was possible to protect oneself and one's livestock from these witches before they stole one's luck without consulting a cunning person (SLS 527: 440-441).

The belief legends do not necessarily name these people, but refer to them as påskkäringar 'old Easter women', trollpackorna 'witches' or trollkäringar (SLS 280: 541; SLS 521: 208; SLS 581: 263). However, it was considered important to identify the harm-doer whenever possible (SLS 524: 145-146; SLS 533: 756), and in some cases the name of the luck stealer is given in the belief legend (SLS 524: 276). The bad reputation of a certain woman who was known to steal luck during Easter might also be mentioned in the memorates (SLS 524: 448). Identification was otherwise facilitated by hard liquor (SLS 524: 206), for example.

Sometimes folk beliefs about Easter witches and Laplanders, for example, were intermingled (SLS 513: 115), but most of the witches in Ostrobothnian belief legends are women from the neighbourhood. This follows the international perception of witches as tending to be women. It may be that old women were among the most vulnerable in their society (Thomas 1991 [1971]: 671-672), but it could also reflect the fact that women were in charge of the household dairy supplies and therefore also of successful butter making (Östman 2008: 180-181). In Ostrobothnia, there were other prejudices against women in general, as these examples show: "If one goes on a journey and meets a 
woman, one should turn around, but if one meets a man it means good luck" (SLS 521: 128-129); and "Meeting a woman brings misfortune, whereas meeting a man means good fortune" (SLS 524: 474).

One could protect one's cattle from witches, and it did not require specialised knowledge, but farmers could keep their knowledge of how to protect their property from other people in the village (SLS 524: 525). The folk belief narratives show some tolerance of witches who stole luck, but they may have faced physical violence when people came across them (Stark 2007: 23), as the following examples demonstrate: "If a woman lost her butter luck, an old man should go to the person who had stolen it and hit her, that would help" (SLS 521: 378); and "Once, a girl ran across the street in front of the bridal wagon, and the groom felt pain. If he had managed to hit the girl such that her blood trickled, he would not have felt the pain." (SLS 524: 49)

It seems that hurting the malevolent person hard enough to draw blood (SLS 524: 295-296; SLS 533: 13) was a means of reducing his/her supranatural power in Ostrobothnian folk beliefs. The belief that wounding a witch so as to make his/her blood run would restore the hurt party's health was also common in other parts of Europe (Thomas 1991 [1971]: 633-634). Wounding a neighbour's wife could also reveal the true identity of a witch (SLS 527a: 442).

People who stole cattle were never named even though they may well have been members of competing households (Stark 2004: 78; see also 2007: 20-21). Contrary to belief legends about outside groups, these narratives refer to threat from within the community. Such practices were perhaps the most persistent among peasant culture in Finland in general. (Stark 2004: 69) Nevertheless, folk beliefs about Easter witches closely resembled beliefs about supranormal beings showing their catch in Blåkulla to their master, the Devil (SLS 521: 210-211).

Women of the farmstead had to work in close proximity. Marriage determined who became new members of the household (Stark 2004: 73-74), therefore weddings are frequently mentioned in archival material concerning folk beliefs about people with supranormal powers (23/299). Wedding celebrations lasted for several days of eating, drinking and dancing (SLS 521: 90-123). According to the archived data, jealous people (see for example SLS 324: 2, 4-6; SLS 521: 389 on protecting weaving from jealous people and the evil eye) sought to harm the bride or groom on these occasions, but it was possible to protect the wedding couple by throwing ash after those who were thought to engage in witchcraft against them (SLS 163: 20-21), or shooting into the air (SLS 231: 117).

A cunning person could heal a victim of witchcraft at a wedding by bathing him/ her (SLS 10: 590-591), thereby fulfilling his role as the power that controls fortune from within the community. Jealousy could also drive someone who was not a member of the immediate group to make many of the wedding guests ill (SLS 231: 143). Relationships between people were generally known. The belief legends exemplify common mental models of what happens when people experience jealousy because they or their families are somehow perceived as having fallen behind, and are therefore expected to express hidden aggression towards other, more fortunate members of the community (Foster 1965: 302).

A jealous suitor, or an unmarried girl's mother who was disappointed that a groom did not choose her daughter, could try to make the bride or groom ill at the wedding 
(SLS 372: 186-189). Cunning people could also be talked into harming the bride through witchcraft (FMK 158 a: 676). This contradicts the notion that, because breaking up the betrothed or married couple was considered a major wrong-doing members of the household who did not approve of the coming marriage could not contact cunning folk for help, so had to wield any harmful magic themselves (Stark 2004: 74). Members of the peasant community who felt threatened applied individualistic survival models (Foster 1965: 301), in this case trying to bring about an unpleasant outcome for a relationship between other people. Nevertheless, the aforementioned examples support Laura Stark's (2004: 78) claim that when harmful magic was presented as witchcraft it did not require specialised knowledge: anyone could conjure illness among their enemies (for example SLS 524: 45; SLS 531: 41). Once bewitched as far as madness, a person could even drive his/her enemies to suicide by means of magic (SLS 524: 209). I will return to the cunning folk later, but it should be noted at this point that they were also able to heal madness (SLS 531: 147), and therefore to restore balance in the community.

An example from Kronoby shows how a new wife tries to find a remedy for her husband who has fallen ill because of a jealous mother's witchcraft:

The wife went to the pastor, after having sought help from doctors a couple of times but the husband was no better despite the medicine they prescribed. When the pastor heard how the man had fallen ill he simply said: Such a disease, such a remedy (meaning that the wife was free to consult a male witch). (SLS 372: 186-189)

Interestingly, this belief legend shows how a representative of the official Lutheran religion reacted when someone approached him with a problem caused by witchcraft.

Pastors (6/299) who represented the official religion lived among the community, but belief legends and memorates about cunning folk refer to priests or the Church in only a few instances. Contrary to what had happened in Denmark over a century earlier (Tangherlini 2000: 281), it seems that at the beginning of the 20th century the Church and cunning folk were not represented as contradicting each other. A pastor named Hartman is said to have burned many witches in Vörå, and to have adopted a witch's son who had already learned many tricks from his mother (SLS 22: 27). In another reference, a priest sees a wandering girl from Lapland whom he had taken under his roof, obtaining milk from a wall. The girl tells him that if she milks more, the sexton's cow will die. The pastor urges her to continue, and the cow dies. The pastor takes responsibility for this and pays for the sexton's cow before banishing the girl. (Wessman 1931: 527) Another pastor named Moliis, who seems at first glance to be curious about tasks frequently attributed to the cunning folk, worked in Korsnäs as a teacher or an assistant pastor. It was said that he looked for souls in a churchyard (SLS 212: 155). Graveyards were powerful locations and their power could be used both malevolently and benevolently. For instance, a cunning man called Riback-smeden ('Riback the Smith') took the sick to graveyards and empty churches to heal them (SLS 524: 211).

A different kind of narrative from Petalax tells of a male witch who threatens to make a priest ill, but even though he recites a charm he cannot make this pastor sick because of his strong faith (SLS 159b: 37-38). These narratives portray pastors in opposition to witches as curious about them, as in the story of the pastor and the girl who obtains milk from a wall. I understand Moliis in Korsnäs as a cunning-folk type of agent. He does not do any harm with the dead, he merely makes them visible to the man inside the ring. The same belief legend tells of cunning men Himis-Hejk, VasjåsMossin, Håpiaseppä, and Lärk Janne. (FMK 158 a: 613, 32, 371; SLS 65: 91-92) 
The need to protect livestock and farms from malevolent magic practised by people living in the community was commonly acknowledged and is evidenced in belief legends that also established societal values. Contrary to what Douglas (2002 [1966]: 130) proposes, in my view the malevolent power that was inherent in the structure was wielded by the aforementioned people. However, there were people who represented the formal structure and who could affect the power balance within a society with their supranormal skills.

\section{CUNNING FOLK AS CONTROLLERS OF FORTUNE AND MISFORTUNE}

Certain people, sometimes named but frequently referred to simply as trollgubbe 'witch man' or kloka gumma 'wise woman', had special knowledge enabling them to carry out important and necessary supranormal tasks in the community. These people, also called cunning folk in the academic literature, were respected by their local communities for their skills in healing (37/299) and other matters (57/299) that required specialised knowledge (see also Midelfort 1974: 195-196). They are referred to in the archived material as trollkunniga or trolldomskunniga 'skilled in witchcraft', which does not translate well into English. Words such as trollkarl, trollkäring and trollgubbe are used in the data for different groups of people, both ingroup and outgroup. The informants do not make clear which of these pose a threat to the community, and which do not, and for this reason I would rather consider the word neutral without strong connotations. However, I cannot deny that it has negative undertones, or that it implies the practicing of malevolent witchcraft. Nevertheless, it seems to be more neutral in the 19th-century data, and possibly also enabled informants to distance themselves from moral questions if it was ethically right to exercise supranormal skills (see also Stark 2004: 69). I use terms that appear in the source materials as indicators of the use of specialised knowledge, which in some cases is difficult to distinguish if the person concerned has had the role of expert (de Blécourt 1994: 296).

As Owen Davies (2003: XIII) puts it, "cunning-folk applied practical magical solutions to resolve everyday problems". They were not interested, or at least according to the archival material did not engage in 'high magic' or occultism, but rather used their knowledge to help those around them, as described in this memorate of a man named Koll-Matts: "The man was called Koll-Matts and he was from Karby [in Pedersöre]. He never did any harm to anyone with his secret knowledge, but he helped as many as he could." (Wessman 1931: 511-512) However, it should be kept in mind that the term 'cunning folk' is an overall concept and therefore one cannot draw strict lines that characterise those who exercised supranormal powers on behalf of their community (de Blécourt 1994: 299). The power to heal and to read other people's thoughts without resorting to witchcraft was also explicitly attributed to a cunning man named Edvard Ekholm (SLS 339: 216-217). It seemed important in these instances for the informant to relate a belief narrative that distinguished the cunning man from witches. However, some belief legends show cunning men in a more ambivalent light. According to such a legend from Terjärv, a cunning man named Savela-Kalle (notably, a Finnish name) wanted to inflict illness upon the person who had bewitched another such that he fell 
ill. However, the patient did not wish him to do so even though what Savela-Kalle had told him about the origin of his illness was true. (SLS 531: 41-43)

Various tasks were attributed to the cunning folk. Language barriers between speakers of Swedish and Finnish did not stop people from seeking help from a famous cunning person who might speak a different language (SLS 527: 508-509). One, and perhaps the most important, task of cunning people related to healing. Almost all of them had some kind of power or knew how to heal other people and livestock (SLS 524: 48-49). However, special knowledge was required if the ailment was more serious (see for example SLS 524: 39). Health care was non-existent in Finnish rural areas and those who could successfully help people in need were highly respected (Stark 2007: 11; SLS 521: 426). Healers who could cure illnesses were called omlagare, 'healers', in Ostrobothnia, and their practice was omlagning, 'healing' (Forsblom 1927: 1). Cunning persons were associated with doctors and not with ritual or spiritual specialists $(6 / 299$, see for example SLS 10: 592; SLS 163: 18-19; SLS 215: 42; SLS 220: 80-81; SLS 524: 77; SLS 533: 16a-16b). Similarly, Finnish tietäjäs, 'those who know', were not religious figures in their communities in eastern Finland but rather based their authority on personal power and secret knowledge (Stark 2007: 9-10), reflecting the Swedish-language material on cunning folk.

According to the belief legends, the cunning folk's healing skills could be more effective than prescribed medicine (see also SLS 524: 286). One relates how Himis-Hejk helped a man in a county hospital in Gamla Vasa by preparing medicine for him in the hospital's kitchen. A doctor asks Himis-Hejk what he is doing, but nevertheless allows the cunning man to proceed. Himis-Hejk's medicine eventually heals the patient, and is soon, according to the belief legend, being used in hospitals around Finland. (FMK 158 a: 20; see also SLS 892: 448-449 about a woman whose ailment was healed by a cunning man when other methods failed.) Korsholm further reports that Zackarias Byrman stopped blood flow so efficiently that doctors even trusted him in the operating room (SLS 533: 27-28). These narratives attest to the power of the cunning folk over official medicine and healthcare. They could also indicate a shift in the provision of healthcare in rural areas, as doctors with academic training in healing replaced the cunning folk. However, this question is beyond the scope of this article and needs further research.

Belief legends tell of priests and doctors who instruct their patients to visit cunning folk because they can better help those in need (FMK 196 b: 72-74; see also Stark 2004: 78-80), although there is no evidence in the belief legends that the cunning folk advised people to visit a doctor if their remedies failed. Such practices seem to contradict what Thomas (1991 [1971]: 314) observes about post-Reformation England, where the clergy saw the cunning man as a competitor. It may also indicate that the Lutheran church was sufficiently strongly established in premodern Finland for the cunning folk not to be considered a threat, despite the aforementioned belief legend from Petalax in which the cunning man challenges the local pastor (SLS 159b: 37-38). Famous cunning folk could also attract patients from nearby regions beyond their own villages (FMK 158 a: 588; SLS 892: 278). Some of their practices involved the use of hard liquor, from which they could see who had done harm to their patients (SLS 531: 526-527; SLS 533: 13), and which also helped them to find lost property (SLS 513: 195; SLS 220: 78; SLS 521: 178; SLS 524: 297-298). 
Cunning folk who represented the formal structure helped to find stolen goods and animals (26/299, for example SLS 524: 293; SLS 527a: 508, 510-511, 513; SLS 533: 19). Interestingly, finding drowned people was a task that common people could carry out, which did not require specialised knowledge (SLS 28: 56; SLS 215: 34; SLS 524: 455). As Thomas (1991 [1971]: 257) argues, "the main task of the cunning folk was to isolate the guilty. The cunning folk's aim was to point out the guilty whom the patient had already suspected and enable the client to act upon his previous suspicions". He further points out that they were often unpopular among other people because they knew too much about the internal conflicts in the community (ibid.: 290). However, and contrary to what Thomas suggests, it seems from the data on finding thieves and stolen goods collected for this article that the names of thieves are seldom given in the belief legends and memorates. This reflects what Willem de Blécourt (1994: 297-298) has pointed out, that the cunning folk left the patients to decide who had trespassed against them. According to the belief legends, cunning folk could say that the evil that befell a person's cattle could reside in other buildings belonging to the farmer who had lost his property, without indicating specifically who might have stolen the animals. (SLS 527: 509)

Cunning folk frequently visited graveyards (SLS 215: 66-68; SLS 220: 260-261; SLS 892: 452-453), or saw the thief in liquor or in coffee (SLS 524: 287), and then revealed where the stolen goods could be found without naming the person who had taken them. However, according to some belief narratives about people who are seriously harmed by another, the cunning person can see the name of the perpetrator in hard liquor (SLS 524: 284-285).

However, on some occasions the name given is false. The informant who related how cunning folk used to visit graveyards to obtain information about thieves continues her narrative. A well-known cunning woman, Lurkkon, named the wrong thief because, as explained in this narrative, the dead she consulted about the theft gave her the wrong information. In the end, the wife of the man whose money was stolen confessed on her deathbed that she had taken it. (SLS 215: 66-68) Nevertheless, it seems probable that Lurkkon was widely known for her ability to force thieves to return stolen goods because several memorates attest to her doing so (FMK 158 a: 676). The implication here is that her power to wield fortune was also appreciated in nearby regions. Naming the thieves, or merely threatening to reveal the person's name might have been enough to make the guilty return the goods. It might have been just as well that cunning folk such as Lurkkon trusted local gossip regarding the identity of the thief. (Stark 2007: 18-19)

Cunning folk could also pose an ingroup threat to the community (12/299). A memorate from Vörå tells of an informant who consulted Himis-Hejk to relieve her pain, however, he told her that he could not help her. From this the informant concluded that it was Himis-Hejk who had cast the spell on her. In the end, she was healed by BrammMatt. (FMK 158 a: 160-161) Evidence from the Finnish accounts of tietäjäs indicates that it was frequently the case that the name of the malevolent agent was not known until healing efforts began (Stark 2007: 15). The above-mentioned informant continues her narrative. Himis-Hejk had also bewitched the whole vicarage of Maxmo, including the pastor, who were healed by another unnamed cunning man. It was commonly thought that the one who had caused the illness could not cure it. (SLS 163: 19) The reasons behind the cunning folk's bewitchment activities are not included in the belief legends, which nevertheless do tell of attitudes presenting trollkarlar as a threat to their 
own communities because they knew how to inflict illness (see also SLS 163: 18-19), but not because they knew too much about the internal conflicts within the community, for example.

Inflicting illness or other harm on members of a community is not a feature that is unique to Swedish-speaking Ostrobothnian cunning folk. Such abilities are usually attributed to witches (Tagherlini 2000: 284-285), and Ostrobothnian folklore supports this separation. As one of the most famous Swedish-language folklorists, Valter W. Forsblom (1927: 1), argues, healers did not wish to associate themselves with trollkarlar or trollpackor. According to his findings, healing had to occur in the name of the Father, the Son and the Holy Spirit, and patients did not want to seek help from the Devil. Those who inflicted illness on people committed a grave sin. (Ibid.) However, as noted earlier, informants also refer to trollkarlar and trollgubbar when describing healing rites. This could be a local variation, meaning that these words lost their sinister emphasis in terms of how informants talked about cunning folk.

The cunning folk of Ostrobothnia used external, controlled power when reciting charms or casting spells on people (Douglas 2002 [1966]: 122-123). Those outside of the social structure such as tattare and Laplanders used uncontrolled and dangerous powers, including evil thoughts and the onset of illness. They brought disorder with them, which individuals within the community regulated by throwing ash in their path. (Ibid.: 123-124, 127; see also SLS 513: 194)

\section{CONCLUSION}

My aim in this article was to study three distinct groups of people who affect the form and structure of the community and regulate its balance by means of supranatural skills, and to analyse how the mental model of limited good affected how people regulated fortune and misfortune in rural bilingual Ostrobothnia in the late 19th and early 20th centuries. The belief legends and memorates about the cunning folk underline their influence in the community in terms of possessing powers that were inherited but potentially lethal, such as the power of the dead. Inherent power within a community was also used by nameless Easter witches and jealous mothers or suitors whose aim was to steal luck from other people. Luck was considered a property that, like money and other goods, could be stolen by those with supranormal skills. Language in itself did not represent other people as outsiders in the belief narratives, but other kinds of livelihood and coming from outside the village community identified people as being from the outgroup and engaging in malevolent witchcraft against members of the community who did not behave in a morally right manner towards those in need. This also placed emphasis on members of the community as regulators of their own fortune, even if they could turn to cunning folk when their own power was insufficient.

\section{NOTES}

1 Cultural models are formed in a community that shares a cultural background (Keesing 1987: 373-374). They contain shared and public world-ordering models that become apparent in a person's worldview or in belief legends (see for example Siikala 2002: 56-57). 


\section{SOURCES}

FMK $=$ Collections of the Dialect Commission. Institute for the Languages of Finland, Swedish Department, Helsingfors (Folkmålskommissionens samlingar. Institutet för de inhemska språken, svenska avdelningen, Helsingfors)

FMK 139 b Birgit Eriksson, Etnografi och folklore, Tenala, 1939-1943.

FMK 158 a Gunnar Rosenholm, Säljakt och sälnätsfiske. Excerperad för ordregistret, Larsmo, Vörå, Kvevlax, Björköby, Replot Korsholm, Solv, Malax, Bergö, Petalax, Korsnäs, Närpes, Pargas, 1953-1955, 1966, 1968.

FMK 196 b Ann-Marie Ivars, Etnografiska och folkloristiska anteckningar om bl.a. gudstjänst och nattvardsgång, folkmedicin, folktro, Närpes, 1967-1972.

SLS = The Society of Swedish Literature in Finland (Svenska Litteratursällskapet i Finland)

SLS 10 Henrik Ståhl, Traditionsuppteckningar, 1890.

SLS 22 Mårten Thors, Traditionsuppteckningar, 1891.

SLS 25 Theodor af Reeth, Visor, folktro och folkmedicin, 1891.

SLS 28 Mårten Thors, Traditionsuppteckningar, 1892.

SLS 33 Karl Petter Pettersson, Folktro och kortspel, 1893.

SLS 65 Johannes Dahlbo, Traditionsuppteckningar, 1898.

SLS 91 Hugo Törnqvist, Traditionsuppteckningar, 1903.

SLS 116a Väinö Solstrand, Traditionsuppteckningar, 1907.

SLS 159b Gustaf A. Hedberg, Österbotten särskilt Oravais och Pedersö. Skrock och vidskepelse. 1894.

SLS 163 Mårten Holmberg, Om vidskepelsen i Vörå. Företag, hållet den 3 februari 1879 vid Svenska landsmålsföreningens årsmöte af M. Holmberg, 1879.

SLS 211 V. E. V. Wessman, Traditionsuppteckningar, 1912.

SLS 212 Petter Edvard Ohls, Traditionsuppteckningar, 1912.

SLS 215 Jacob Tegengren, Folkminnen, 1912-1913.

SLS 220 Elever vid Kronoby folkhögskola, Johannes Klockars, Uppsatser om traditionsvetenskapliga ämnen, 1913.

SLS 231 K. Rob. V. Wikman, Bröllopsseder, 1914.

SLS 254 Oskar Holmqvist, Seder och bruk vid olika bemärkelsedagar i Kronoby och Teerijärvi, 1914.

SLS 280 V. E. V. Wessman, Sägner och gåtor, 1917.

SLS 319 Elever vid Närpes folkhögskola, Uppsatser om folktraditioner, 1921.

SLS 324 Jacob Tegengren, Folkloristiska uppteckningar, 1918-1921.

SLS 339 Elever vid Svenska folkakademin, Uppsatser om folktraditioner, 1922.

SLS 372 Vivi Peters, Traditionsuppteckningar från Karleby, Esse och Nedervetil, 1925.

SLS 513 Erla Lund, Folksed, folktro och lekar, 1929.

SLS 521 Erla Lund, Folksed och folktro, Pedersöre, Munsala, Korsnäs. 1930.

SLS 524 Erla Lund, Folksed och folktro, Malaks, Pörtom och Övermark. 1931.

SLS 527a Erla Lund, Folktro och folksed, 1932.

SLS 531 Erla Lund, Folktro och folksed, 1934.

SLS 533 Erla Lund, Folktro och folksed, 1933.

SLS 554 Heimer Björkqvist, Ord och uttryck $i$ samband med folktro, 1939.

SLS 581 Ragna Ahlbäck, Uppteckningar för Atlas över svensk folkkultur, 1945.

SLS 892 Johan Oskar Imanuel Rancken, Kopior av elevuppsatser $i$ Ranckens samling, 1866-1887.

ULMA = The Institute for Language and Folklore (Institutet för språk och folkminnen)

ULMA 24345. B. Olof Bondesson 1960. SMÅL. GULLABO Frgl. M 100.

ULMA 9408. C. Franzén. 1936. GOTL. Frgl. M 100. 


\section{REFERENCES}

Andersson, Otto. 1967. Finländsk folklore: Tidig kalevalaforskning Finlandssvensk insamlingsverksamhet. Åbo: Åttas förlag.

Anttonen, Veikko. 1996. Ihmisen ja maan rajat: 'Pyhä' kulttuurisena kategoriana. Suomalaisen Kirjallisuuden Seuran Toimituksia 646. Helsinki: Suomalaisen Kirjallisuuden Seura.

Asplund Ingemark, Camilla. 2006. The Chronotype of Enchantment. - Journal of Folklore Research 43 (1): 1-30. DOI: https://doi.org/10.2979/JFR.2006.43.1.1.

Bladh, Gabriel and Christer Kuvaja. 2005. Från ett rike till två nationastater. - Dialog och särart: Människor, samhällen och ideér från Gustav Vasa till nutid. Svenskt $i$ Finland - finskt i Sverige 1, edited by Gabriel Bladh and Christer Kuvaja. Helsingfors: Svenska litteratursällskapet i Finland, 11-41.

de Blécourt, Willem. 1994. Witch Doctors, Soothsayers and Priests: On Cunning Folk in European Historiography and Tradition. - Social History 19 (3): 285-303. DOI: https://doi. org/10.1080/03071029408567910.

Davies, Owen. 2003. Popular Magic: Cunning-folk in English History. Hambledon; London: Continuum.

Douglas, Mary. 2002 [1966]. Purity and Danger. Routledge classics. New York, NY: Routledge.

Forsblom, Valter W. 1927. Finlands Svenska folkdiktning VII. Folktro och trolldom. 5 Magisk Folkmedicin. Helsingfors: Svenska Litteratursällskapet i Finland.

Foster, George M. 1965. Peasant Society and the Image of Limited Good. - American Anthropologist 67 (2): 293-315. DOI: https://doi.org/10.1525/aa.1965.67.2.02a00010.

Herberts, Kjell and Börje Vähämäki. 1998. "At Home They Long for Far Away, Abroad They Yearn for Home": Swedish-Speaking Ostrobothnia. - Journal of Finnish Studies 2 (2): 20-26.

Honko, Lauri. 1959. Krankheitsprojektile: Untersuchung über eine urtümliche Krankheitserklärung. Helsinki: Academia Scientiarum Fennica.

Itkonen, Toivo. 1955. Lappi ja lappalaiset vanhoissa kansanrunoissamme. Lapin sivistysseuran julkaisuja 20. Helsinki: Lapin sivistysseura.

Jauhiainen, Marjatta. 1998. The Type and Motif Index of Finnish Belief Legends and Memorates. Folklore Fellows' Communications 267. Helsinki: Academia Scientiarum Fennica.

Keesing, Roger M. 1987. Models, "Folk" and "Cultural": Paradigms Regained? - Cultural Models in Language and Thought, edited by Dorothy Holland and Naomi Quinn. Cambridge: Cambridge University Press, 369-393. DOI: https://doi.org/10.1017/CBO9780511607660.016.

Lakoff, George. 1987. Women, Fire, and Dangerous Things: What Categories Reveal about the Mind. Chicago, IL; London: The University of Chicago Press.

Lindgren, Klaus and Anna-Riitta Lindgren. 2005. Språkbyten bland ståndspersonerna i storfurstendömet Finland. - Dialog och särart: Människor, samhällen och ideér från Gustav Vasa till nutid. Svenskt i Finland - finskt i Sverige 1, edited by Gabriel Bladh and Christer Kuvaja. Helsingfors: Svenska litteratursällskapet i Finland, 256-319.

Mattila, Tiina. 2016. Peilipojasta tarinoimassa. Tyrvänäläisen kerrontaperinteen performanssit 2000-luvulla. - J@rgonia 14 (28): 84-106. http://urn.fi/URN:NBN:fi:jyu-201612095006 (accessed November 13, 2019).

Midelfort, H. C. Erik. 1974. Were There Really Witches? - Transition and Revolution: Problems and Issues of European Renaissance and Reformation History, edited by Robert M. Kingdon. Madison, WI: University of Wisconsin, 189-205.

Österlund-Pötzsch, Susanne and Carola Ekrem. 2008. Swedish Folklore Studies in Finland 18281918. The History of Learning and Science in Finland 1828-1918. Vammala: Societas Scientiarum Fennica.

Östman, Ann-Catrin. 2008. Traditions of Gender, Class, and Language: Cooperative Organizing in a Finland-Swedish Community. - Societal Change and Ideological Formation among the Rural 
Population of the Baltic Area 1880-1939. Studia Baltica II: 2, edited by Piotr Wawrzeniuk. Huddinge: Södertörns högskola, 169-185.

Siikala, Anna-Leena. 2002. Mythic Images and Shamanism: A Perspective on Kalevala Poetry. Folklore Fellows' Communications 280. Helsinki: Suomalainen tiedeakatemia.

Stark, Laura. 2002. Peasants, Pilgrims, and Sacred Promises: Ritual and the Supernatural in Orthodox Karelian Folk Religion. Studia Fennica Folkloristica 11. Helsinki: Finnish Literature Society. DOI: https://doi.org/10.21435/sff.11.

Stark, Laura. 2004. Narrative and the Social Dynamics of Magical Harm in Late Nineteenth- and Early Twentieth-century Finland. - Witchcraft Continued: Popular Magic in Modern Europe, edited by Willem de Blécourt and Owen Davies. Manchester: Manchester University Press, 69-88. https://ebookcentral-proquest-com.libproxy.helsinki.fi/lib/helsinki-ebooks/detail. action?docID=589296 (accessed September 19, 2019).

Stark, Laura. 2007. Sorcerers and Their Social Context in 19th-20th Century Rural Finland. - Arv. Nordic Yearbook of Folklore (63): 7-29.

Spooner, Brian. 2013 [1970]. The Evil Eye in the Middle East. - Witchcraft Confessions and Accusations, edited by Mary Douglas. Hoboken, NJ: Taylor and Francis, 311-319. http://search. ebscohost.com.libproxy.helsinki.fi/login.aspx?direct=true \&db=nlebk\&AN=570337\&site=eh ost-live\&scope $=$ site (accessed August 7, 2019).

Tangherlini, Timothy R. 2000. “How Do You Know She's a Witch?": Witches, Cunning Folk, and Competition in Denmark. - Western Folklore 59 (3/4): 279-303. DOI: https://doi. org/10.2307/1500237.

Tarkka, Lotte. 2013. Songs of the Border People: Genre, Reflexivity, and Performance in Karelian Oral Poetry. Folklore Fellows' Communications 305. Helsinki: Academia Scientiarum Fennica.

Thomas, Keith. 1991 [1971]. Religion and the Decline of Magic: Studies in Popular Beliefs in Sixteenthand Seventeenth-Century England. London: Penguin.

Uotila, Merja. 2018. Maaseutukäsityöläisten sosiaalinen asema ja keskinäinen hierarkia esimodernissa Suomessa. - Reunamailla: Tilattomat Länsi-Suomen maaseudulla 1600-1800. Historiallisia tutkimuksia 278, edited by Riikka Miettinen and Ella Viitaniemi. Helsinki: Suomalaisen Kirjallisuuden Seura, 98-126.

Vuorela, Toivo. 2019 [1960]. Paha silmä suomalaisen perinteen valossa. Kirjokansi 210. Helsinki: Suomalaisen Kirjallisuuden Seura.

Wessman, V. E. V. 1931. Finlands Svenska folkdiktining II. Sägner. 3 Mytiska Sägner. 2 Sägner till typförteckningen. Helsingfors: Svenska Litteratursällskapet i Finland. 